\title{
Study Site Identifier
}

National Cancer Institute

\section{Source}

National Cancer Institute. Study Site Identifier. NCI Thesaurus. Code C83081.

A sequence of characters used to identify, name, or characterize the study site. 